\title{
MENINGKATKAN BUDAYA LITERASI MELALUI PENGELOLAAN TAMAN BACAAN DI DESA KEMIRI KECAMATAN PACET KABUPATEN MOJOKERTO
}

\author{
Fajar Susanto ${ }^{1)}$, Rahmad Hidayat ${ }^{2}$, Endang M. Rahayu ${ }^{3)}$, \\ Hertiki $^{4}$, Armelia N. Arbani ${ }^{5)}$ \\ 1,2,3,4,5 Universitas PGRI Adi Buana Surabaya \\ Email:1fajarsusanto@unipasby.ac.id
}

\begin{abstract}
Abstrak
Rendahnya minat baca menjadi permasalahan utama di Indonesia yang harus dipecahkan oleh pemerintah dan menjadi perhatian berbagai kalangan khususnya universitas dan pemerhati literasi. Pengabdian masyarakat ini bertujuan untuk meningkatkan budaya literasi melalui pengelolaan Taman Bacaan di desa Kemiri Kecamatan Pacet Kabupaten Mojokerto. Dengan pelaksanaan program ini, Masyarakat Desa Kemiri telah mendirikan Taman Bacaan dan juga sadar tentang pentingnya literasi bagi masyarakat desa, belajar mengelola Taman Bacaan dengan baik dan profesional, dan dapat menghidupkan program desa terkait dengan pendidikan dengan kegiatankegiatan literasi yang mengedukasi serta membuat masyarakat menjadi produktif.
\end{abstract}

Kata Kunci: literasi, pengelolaan taman bacaan, budaya membaca

\section{Abstract}

The lack of reading interest becomes the main problem in Indonesia that must be solved by the government and becomes the concern of various elements, especially universities and literacy observers. This community service aims to improve the literacy culture through the management of mini library in the village of Kemiri, Pacet District, Mojokerto Regency. By implementing this program, the people of Kemiri have built Taman Bacaan (mini library) and are also aware of the importance of literacy for the people of the village, learn how to manage mini library properly and professionally, and can activate the village programs in terms of education by organizing literacy activities that educate and make Kemiri people productive.

Keywords: literacy, mini library management, reading culture

\section{PENDAHULUAN}

Berdasarkan laporan survei yang dilakukan PISA 2019 dan telah rilis pada bulan Desember 2019, peringkat Indonesia dalam hal membaca berada pada posisi 72 dari 77 negara yang ikut berpartisipasi (Kurnia, 2019 liputan6.com). Indonesia tertinggal secara signifikan dengan Singapura dan Malaysia di mana Malaysia naik pada level tengah dari 77 negara, sedangkan Singapura tetap menduduki peringkat teratas. Ini menandakan bahwa budaya membaca pada umur 15 tahun atau kalangan pelajar di
Indonesia sangat rendah. Kondisi seperti ini tentu memperihatinkan bagi kita semua di mana keberlangsungan pembangunan Indonesia bergantung kepada generasi muda yang cerdas untuk melanjutkan pembangunan ke depan.

Rendahnya budaya membaca ini tentunya tidak hanya menjadi perhatian besar pemerintah tetapi juga Perguruan Tinggi dan pemerhati literasi di Indonesia. Harus ada upaya nyata dalam menindaklanjuti laporan PISA tersebut. Semua elemen bangsa tidak ingin generasi kita dipandang sebelah mata di 
dalam persaingan global oleh Negara-negara lain karena generasi muda kita adalah generasi pemalas, tidak suka membaca, dan tentunya hal ini juga berpengaruh pada budaya belajar, khususnya membaca dan menulis. Hal ini ditegaskan oleh Chiu (2015) bahwa membaca dan menulis adalah fondasi bagi pendidikan dan perkembangan bahasa dan merupakan sentral dari proses belajar.

Untuk menjadikan masyarakat senang membaca sejak usia dini perlunya pemberdayaan Taman Bacaan Masyarakat. Program literasi itu tidak hanya didorong di sekolah-sekolah di mana sekolah sebagai tempat yang banyak berpengaruh terhadap proses membaca dan menulis (Susanto and Rifai, 2018), akan tetapi desa-desa juga perlu perhatian besar karena desa merupakan tempat masyarakat berkelompok, bertempat tinggal, dan berinteraksi sosial, sehingga program literasi juga bisa digalakkan di desadesa tersebut. Pentingnya program literasi di desa ini yaitu untuk mendorong generasi muda berkembang secara intelektual, cerdas, berwawasan luas, dan penuh dengan ide-ide yang cemerlang. Selain itu, yang paling utama adalah menumbuhkan kesadaran (awareness) kepada anak usia dini, bahwa budaya membaca dan menulis merupakan praktik-praktik sosial yang harus ditanamkan sejak dini, di mana menurut Rifai dan Fajar (2017), intervensi harus dilakukan oleh pemangku jabatan dan pembuat kebijakan untuk meningkatkan kesadaran membaca dan menulis sejak usia dini. Namun begitu, program literasi di desa juga harus didukung oleh masyarakat dan orang tua.

Selain itu, untuk meningkatkan dan mensukseskan program literasi di desa dibutuhkan sarana dan prasarana yang mendukung program literasi di desa tersebut, di antaranya perlu adanya sumber belajar berupa Taman Bacaan (perpustakaan) yang menyediakan sumber-sumber bacaan beraneka ragam. Taman Bacaan dibentuk atas dasar keinginan bersama dan menyadari adanya kebutuhan masyarakat untuk maju dan berkembang melalui informasi dan ilmu pengetahuan yang diperoleh secara efektif, cepat, mudah dan murah. Taman Bacaan merupakan fasilitas umum yang terkait dengan sarana pendidikan yang harus disediakan oleh pemerintah desa sebagaimana diatur dalam Permendagri dan otonomi no 3 tahun 2001 tentang penyelenggaraan perpustakaan desa. Fungsi pokok Taman Bacaan ini adalah memberikan pelayanan kepada masyarakat materi-materi pustaka dan informasi serta sebagai tempat hiburan sehat bagi masyarakat.

Namun tantangan yang dihadapi oleh Taman Bacaan desa adalah bukan hanya rendahnya minat baca masyarakat desa, terutama anak-anak, namun menurut Ariyani at al (2017) banyak masalah yang dihadapi oleh pengelolaan Taman Bacaan seperti ketiadaan gedung, koleksi dan SDM yang sangat minim dan antusiasme masyarakat terhadap keberadaan Taman Bacaan juga masih rendah. Mereka belum memiliki kesadaran tentang pentingnya Taman Bacaan bagi mereka dan anak-anak mereka, sehingga pengelolaan Taman Bacaan di desa itu tidak dikelola dengan maksimal.

Minat baca dapat dibentuk atau ditumbuhkan sejak dini. Minat baca anak sangat dipengaruhi oleh situasi dan kondisi lingkungan dimana dia tinggal. Dalam hal ini, peran serta Taman Bacaan desa dan orang tua sangat diharapkan untuk menumbuhkan minat baca anak. Sedangkan pengelolaan Taman Bacaan (perpustakaan) ini merupakan aktivitas-aktivitas Taman Baca yang harus dilakukan dengan sebaik-baiknya agar Taman Bacaan tersebut terus berkembang dan terus memberikan pelayanan kepada masyarakat yang membutuhkan informasi. Oleh karena itu, dalam artikel ini dibahas tentang peningkatan budaya literasi masyarakat desa melalui pengelolaan Taman Bacaan di Desa Kemiri

\section{METODE PELAKSANAAN}

Metode pelaksanaan dalam peningkatan budaya literasi masyarakat desa melalui pengelolaan Taman Bacaan meliputi perencanaan dan pelaksanaan. Perencanaan ini terkait dengan pemilihan desa dan program-program yang dilaksanakan. Pelaksanaan menggunakan metode 
penyuluhan dan pendambingan kepada masyarakat Desa Kemiri, Kecamatan Pacet, Mojokerto. Konsep pemberdayaan dalam program peningkatan Literasi ini menggunakan konsep Gunawan Sumodiningrat dalam Suryanto (2005) yaitu pemberdayaan dengan menciptakan suasana dan iklim yang berkembang dengan melihat potensi dan daya yang dimiliki oleh masyarakat tersebut.

Yang pertama dengan menciptakan suasana dan iklim seperti yang dijelaskan oleh Widjayanti dan Ayuningtyas (2019) bahwa suasana dan iklim pembiasaan membaca harus diciptakan dengan baik di lingkungan masyarakat dengan memberikan penyadaran kepada masyarakat melalui penyuluhan dan yang kedua adalah melihat potensi masyarakat desa untuk mengelolah taman bacaan melalui pendampingan.

Peserta program ini dihadiri oleh 40 peserta yang terdiri dari Pemuda Karang Taruna Desa Kemiri, Ibu PKK Desa Kemiri dan perangkat Desa Kemiri, Kecamatan Pacet, Mojokerto. Dengan penyuluhan dan pendampingan pemberdayaan Taman Bacaan ini, diharapkan muncul kreatifitas-kreatifitas masyarakat dalam menciptakan sesuatu yang baru dan menarik sehingga Taman Bacaan di Desa Kemiri betul-betul berkembang guna mendukung program pemerintah dalam penguatan pembangunan sumber daya manusia di pedesaan.

\section{HASIL DAN PEMBAHASAN}

Berdasarkan hasil kegiatan yang telah dilaksanakan melalui program penyuluhan dan pendampingan, program ini mendeskripsikan tiga poin sebagai berikut.

\section{A. Desa Kemiri dan Program Literasi}

Desa Kemiri adalah desa di dataran tinggi Kecamatan Pacet, Kabupaten Mojokerto. Desa ini berada di dataran tinggi dengan suasana alamnya yang sejuk dan indah. Sebagian besar masyarakatnya adalah petani dan pengrajin, karena Kecamatan Pacet adalah daerah destinasi wisata pegunungan. Oleh sebab itu, desa kemiri juga terdampak oleh adanya pariwasata alam pegunungan daerah Pacet.

Desa Kemiri memiliki akses jalan Utama, sehingga secara ekonomi masyarakatnya tidak tertinggal oleh desadesa di sekitarnya, namun desa Kemiri belum memiliki Taman Bacaan atau perpustakaan desa. Balai Desa Kemiri tidak dijumpai adanya aktivitas masyarakat terkait dengan kegiatan literasi. Oleh sebab itu, melalui program pengabdian dosen-dosen Program Studi Pendidikan Bahasa Inggris Unipa Surabaya, telah didirikan sebuah Taman Bacaan untuk memulai sebuah aktivitas literasi di Desa Kemiri. Program literasi ini didukung oleh Kepala Desa Kemiri dan seluruh perangkat dan masyarakatnya.

Dampak positif dari program literasi ini adalah memberikan dorongan terutama bagi pemuda karang taruna untuk aktif berpartisipasi dalam mensukseskan program di desa mereka. Dampak dari program peningkatan budaya literasi ini di Desa Kemiri adalah (1) tercipta kesadaran masyarakat terhadap pentingnya membaca; (2) terciptanya pembiasaan membaca bagi masyarakat; (3) aktifnya desa sebagai pusat informasi; (4) munculnya kegiatan-kegiatan literasi di desa; (5) taman bacaan desa menjadi hiburan masyarakat di waktu luang.

Literasi sebagai praktik sosial tentunya menjadi peran fundamental dalam kehidupan anak-anak di Desa Kemiri jika praktikpraktik literasi ini berlangsung dengan baik. Perkembangan literasi anak pada usia dini bisa tumbuh dengan baik jika kondisi dan budaya membaca sudah terbentuk dari keluarga dan masyarakat. Jika Orang tua membawa dan mengenalkan kepada anakanak mereka untuk membaca di Taman Bacaan, pembiasaan itu lambat laun tumbuh seiring dari perkembangan anak-anak itu sendiri. Dari situlah, budaya membaca terus berkembang secara terus menerus. Oleh sebab itu, pembiasaan membaca harus diperkenalkan sejak dini. 


\section{B. Literasi dan Budaya Membaca Masyarakat Desa Kemiri}

Peningkatan budaya membaca di pedesaan tidak mungkin bisa dilakukan secara instan dan dalam waktu yang cepat. Untuk mengubah budaya yang tidak senang membaca menjadi senang membaca dibutuhkan usaha kuat dan gigih serta waktu yang panjang untuk mencapai hasil yang diinginkan. Oleh sebab itu, melalui pengabdian masyarakat ini dibutuhkan beberapa langkah untuk menyadarkan masyarakat tentang pentingnya budaya membaca bagi mereka dan khususnya anakanak usia sekolah.

\section{Taman Bacaan Desa Kemiri}

Seperti disampaikan bahwa Desa Kemiri merupakan desa yang belum memiliki perpustakaan atau Taman Bacaan sehingga aktifitas literasi di desa ini bisa dikatakan pasif dan tidak ada tanda-tanda bahwa di desa ini masyarakatnya senang membaca. Untuk itu, hal utama yang harus dilakukan untuk menumbuhkan dan menciptakan suasana dan iklim senang membaca adalah dengan mendirikan Taman Bacaan di balai desa Kemiri. Kepala Desa Kemiri memberikan sebuah ruang untuk dijadikan Taman Bacaan dan menjadi fasilitas membaca di desa Kemiri dan dikelola secara sederhana, swakarsa, dan swadaya oleh masyarakat dalam rangka meningkatkan minat baca dan mewujudkan masyarakat gemar membaca.

Taman Bacaan Desa Kemiri tidak hanya terbatas di ruang Taman Bacaan yang telah diberikan namun di luar balai desa Kemiri bisa digunakan menjadi sudut-sudut baca dengan tidak meninggalkan estetika, dalam arti sudutsudut baca yang dibuat harus memberikan daya tarik bagi pengunjung atau masyarakat untuk membaca, tetapi balai desa tetap rapi dan keindahan tetap terjaga sehingga balai desa tidak hanya menjadi pusat informasi namun juga menjadi tempat yang menarik bagi masyarakat setempat. Taman Bacaan Desa Kemiri bisa menjadi alternatif hiburan masyarakat setempat untuk membaca dan berkumpul menghabiskan waktu luang bersama keluarga.

\section{Kesadaran terhadap Budaya Membaca}

Untuk mewujudkan masyarakat yang gemar membaca pada masyarakat desa dibutukan pengetahuan dan sikap tentang pentingnya budaya membaca melalui penyuluhan tentang arti pentingnya Taman Bacaan bagi masyarakat. Tidak hanya mengajak masyarakat untuk membaca, tapi harus ada pengetahuan yang diberikan kepada masyarakat terkait dengan program literasi dan manfaatnya.

Hal terpenting yang harus diubah dari masyarakat desa Kemiri adalah sadar literasi (literacy awareness) yaitu perubahan sikap dari tidak mau membaca menjadi mau dan senang membaca. Hal ini ditegaskan oleh Ibrahim et al. (2003) perubahan sikap terhadap hal terjadi apabila ada perubahan sikap terhadap sesuatu yang telah diciptakan dan mau memanfaatkannya dengan baik. Dengan kata lain, pengetahuan-pengetahuan yang diberikan kepada masyarakat dapat membentuk kesadaran mereka untuk berubah dan mau melakukan karena ada banyak manfaat yang mereka dapatkan dari aktifitas membaca itu.

Perubahan sikap ini harus tumbuh dan membentuk sebuah kesadaran di mana membaca tidak lagi menjadi sebuah kewajiban yang seakan-akan mengekang pada pribadi-pribadi, namun membaca telah menjadi kebutuhan yang menyebabkan kehausan dan kelaparan pengetahuan.

\section{Pengelolaan Taman Baca yang Efektif}

Taman Bacaan di sebuah desa tentunya berbeda dengan per-pustakaan besar atau perpustakaan umum lainnya di mana pengelolaannya sangat kompleks. Taman Bacaan masyarakat ini cukup dikelolah secara sederhana dan swadaya masyarakat, namun harus dilakukan 
secara professional. Pengelolaan tersebut meliputi serangkaian perencanaan, pengorganisasian, pelaksanaan dan kontrol dalam upaya mencapai tujuan secara efektif dan efisien.

Perencanaan Taman Bacaan di desa Kemiri sudah dilakukan secara matang seperti penentuan tempat yaitu di balai desa Kemiri dan sudah disediakan oleh Kepala Desa Kemiri dan pengelola Taman Bacaan ini adalah pemuda karang taruna desa Kemiri dengan membentuk organisasi sederhana untuk menjalankan aktifitas tersebut.

Untuk menjalankan aktifitas Taman Bacaan ini dibutuhkan susunan organisasi agar peran dan tugas setiap pengelolah Taman Bacaan berjalan dengan lancar dan setiap orang dapat melaksanakannya dengan baik.

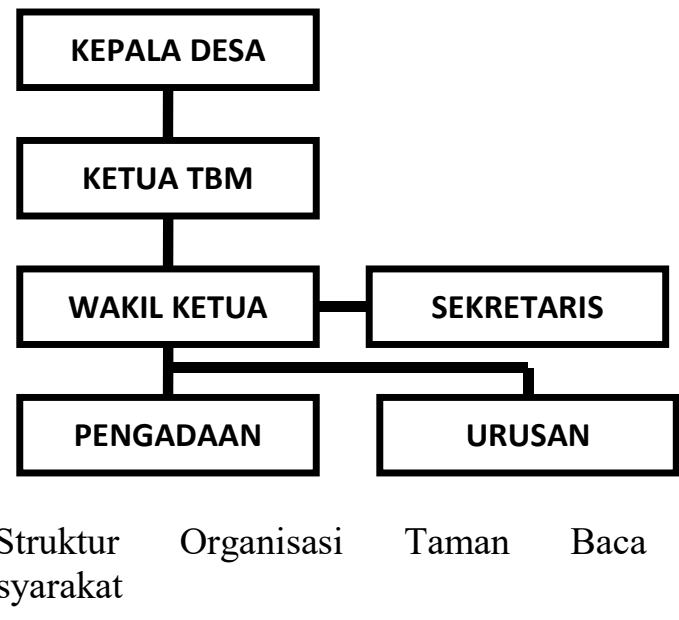

$$
\begin{aligned}
& \text { Pelaksanaan merupakan } \\
& \text { implementasi dari perencanaan- } \\
& \text { perencanaan yang sudah dibuat } \\
& \text { sebelumnya. Pelaksanaan ini harus } \\
& \text { mengacu pada peran, tugas dan tanggung }
\end{aligned}
$$

pelaksanaannya. Pengawasan (controlling) merupakan upaya melihat dan mengukur ketercapaian yang sudah dilaksanakan dengan menggunakan kriteria-kriteria yang sudah ditetapkan sebelumnya. Dengan kata lain, pengawasan ini dimaksudkan untuk mengetahui efektifitas dalam penyelenggaraan Taman Baca

\section{Penambahan Sumber Bacaan}

Setelah mendirikan Taman Bacaan desa Kemiri, maka yang harus dipenuhi adalah pengadaan sumber bacaan. Di awal pembentukan Taman Baca Desa Kemiri, Program Studi Pendidikan Bahasa Inggris Unipa Surabaya telah menyumbangkan 334 buku kepada Taman Baca Desa Kemiri.

Selain buku-buku yang telah ada, pengelola selanjutnya harus memikirkan penambahan dan penataan koleksi buku, agar masyarakat terus datang dan ingin membaca karena selalu ada informasi baru yang mereka dapatkan dari Taman Baca. Oleh sebab itu, pemerintahan desa dan pengelola harus terus berusaha memberikan sumber-sumber bacaan baru agar masyarakat terus datang ke Taman Bacaan karena selalu ada buku-buku baru yang memberikan informasi baru. Koleksi buku yang bervariatif bagi anak-anak dan orang dewasa disediakan berdasarkan dengan kebutuhan. Terkait dengan anggaran pengadaan buku agar keberlangsungan perpustakaan desa berjalan dengan baik harus ada alokasi dari kas desa untuk perpustakaan, sumbangan masyarakat atau sum-bangan dari institusi terkait.

\section{Penyelenggaraan Kegiatan-Kegiatan Edukatif untuk Anak-Anak}

Untuk memberdayakan Taman Bacaan Desa Kemiri, pengelola harus menyelenggarakan kegiatan-kegiatan edukatif yang diselenggarakan oleh pemuda karang taruna dan ibu PKK desa setempat. Taman Bacaan atau perpustakaan desa bukan saja berfungsi sebagai tempat membaca, akan tetapi bisa juga dimanfaatkan sebagai sarana untuk 
melakukan kegiatan-kegiatan edukatif untuk mengembangkan potensi anak, misalnya mengadakan lomba melukis atau mewarnai, lomba menulis, bercerita dan lain sebagainya.

\section{Pendampingan dalam Pengelolaan Taman Baca Desa Kemiri}

Pendampingan dalam mengelola Taman Bacaan Desa Kemiri menjadi salah satu hal terpenting bagi keberlangsungan Taman Bacaan ke depan, sehingga diharapkan melalui pendampingan yang tepat guna, keberadaan Taman Bacaan tidak hanya berjalan dengan baik tetapi juga berlangsung untuk selamanya. Oleh karena itu, beberapa aspek pendampingan yang dilakukan meliputi beberapa hal yang yakni pendampingan (1) aspek anggaran; (2) aspek Sumber Daya Manusia (SDM); (3) aspek layanan; (4) aspek koleksi; dan (5) aspek sarana dan prasarana.

Pendampingan pada aspek anggaran dilakukan dengan memberikan pelatihan singkat tentang pembuatan perencanaan anggaran dalam satu tahun. Perencanaan dilakukan di awal tahun dan evaluasi anggaran dilakukan di akhir tahun. Penambahan koleksi dan perawatan gedung serta kegiatan-kegiatan insidental yang mendukung peningkatan budaya literasi masyarakat seperti lomba bercerita atau yang lain bisa menjadi acuan untuk melakukan perencanaan anggaran bagi pengelola Taman Bacaan.

Selain itu, kegiatan pen-dampingan anggaran dilakukan dengan memberikan arahan tentang peluang sumber dana yang bisa diperoleh. Diantaranya, dana dari desa sehingga komunikasi antara pihak pengelola dengan perangkat desa menjadi penting. Selanjutnya, pendampingan di arahkan pada pembuatan proposal bagi pengelola untuk pengajuan dana baik kepada pemerintah terkait maupun kepada para donatur atau para pengusaha lokal di wilayah Desa Kemiri.

Kedua adalah pendampingan penguatan Sumber Daya Manusia (SDM). Pendampingan SDM meliputi pelatihan dasar kepada pengelola tentang pengetahuan bagaimana mengelola Taman Bacaan secara baik. Pelatihan tersebut diarahkan pada pengetahun umum tentang bagaimana mengelola Taman Bacaan. Salah satu penekanan yang ditanamkan kepada pengelola adalah kemauan mereka untuk terus mau menambah wawasan secara berkesinambungan khususnya mengenai pengembangan Taman Bacaan.

Dua hal yang bisa dilakukan untuk penguatan SDM yakni dengan memperbarui pengetahuan yakni dengan mencari informasi sebanyak-banyaknya melalui internet tentang berbagai hal terkait pengelolaan Taman Bacaan. Kedua yakni dengan melakukan kegiatan studi banding dengan Taman Bacaan di tempat lain yang sudah lebih dulu berkembang dan maju. Ketiga, SDM diberi berbagai informasi terkait kegiatan-kegiatan yang bermanfaat yang bisa dilakukan di Taman Bacaan.

Selanjutnya adalah pendampingan di bidang pelayanan yang sangat terkait dengan aspek sebelumnya yakni kualitas SDM. Jika penguatan aspek SDM menitikberatkan pada aspek intelektual maka aspek layanan lebih pada aspek mental bagi para pengelola Taman bacaan. Terlebih, pada umumnya pengelola Taman Bacaan umumnya merupakan tenaga-tenaga sukarelawan yang tidak dibayar. Oleh karena itu, pemahaman kepada pengelola bahwa mengelola Taman Bacaan merupakan kegiatan sosial yang memberi kemanfaatan bagi masyarakat secara luas menjadi penting.

Dari kesadaran memberi kemanfaatan bagi masyarakat itulah, diharapkan pengelola Taman Bacaan bisa memberikan layanan kepada para pengunjung dengan sepenuh hati sehingga mampu menarik pembaca sebanyak mungkin. Selain itu, aspek fleksibilitas juga penting terkait jam operasional. Layanan bisa diberikan pada sore sampai petang serta Taman Bacaan juga bisa dibuka pada harihari libur sekolah sehingga memberikan kegiatan alternatif yang sangat bermanfaat bagi anak-anak sekolah dan masyarakat pada umumnya.

Pendampingan aspek kelima adalah koleksi Taman Baca yang diarahkan pada 
aspek kebutuhan. Pegiat Taman Bacaan ditanamkan memahami kondisi masyarakat sekitar mulai dari aspek sosial, budaya, pendidikan, ekonomi dan agama sehingga pengadaan koleksi bisa memberikan manfaat lebih pada semua masyarakat yang ingin memanfaatkan layanan Taman Bacaan.

Misalnya kondisi masyarakat Desa Kemiri Pacet secara geografis adalah petani dan memilki budaya agraris yang kuat, serta daerah wisata, maka penambahan koleksi berbasiskan hal-hal tersebut dan buku-buku terkait dengan eknomi kreatif. Meskipun tidak menutup kemungkinan bacaan-bacaan lain sebagai tambahan wawasan. Selain itu, koleksi Taman Bacaan juga diharapkan bervariasi dan menjangkau semua jenjang usia dan pendidikan, mulai dari bacaan anakanak hingga bacaan bagi mahasiswa dan masyarakat umum. Koleksi juga tidak hanya buku, tetapi juga bisa bentuk koran, majalah, poster, peta serta koleksi-koleksi dalam bentuk digital bisa menjadi nilai lebih bagi Taman Bacaan.

Pendampingan aspek terakhir yakni sarana dan prasarana. Penanamanan perawatan sarana dan prasarana Taman Bacaan yang sudah dibentuk menjadi hal yang sangat penting. Terlebih, kelemahan umum masyarakat selama ini adalah merawat fasilitas publik yang menjadi milik bersama. Oleh karena itu, pengelola dan semua masyarakat sekitar dibangun kesadarannya tentang rasa memiliki sehingga dari situ muncul keinginan kuat untuk menjaga dan merawat sarana dan prasarana Taman Baca.

Tiga hal yang menjadi perhatian pada aspek ini yakni gedung, ruang dan perabot. Gedung yang sudah tersedia di kompleks balai desa memberikan keuntungan lebih bagi pengelola karena bisa menjadi media efektif antara pengelola dengan perangkat desa. Sehingga pengelola bisa menjalin komunikasi dengan pihak perangkat jika ingin mengembangkan gedung. Selain itu, balai desa yang merupakan tempat berkumpulnya masyarakat bisa menjadi semangat pengelola untuk mendekorasi gedung Taman Bacaan lebih atraktif misalnya dengan pengecatan yang bagus sehingga menjadi daya tarik yang pada akhirnya mampu menarik masyarakat untuk mengunjungi Taman Bacaan.

Pengadaan perabot semacam meja dan kursi serta karpet juga menjadi hal yang penting. Ditambah pula dengan pengadaan alat peraga semacam peta ataupun poster serta lainnya juga bisa dilakukan oleh pengelola. Hal terpenting dari berbagai aspek pengelolaan Taman Baca adalah kreatifitas. Semakin kreatif pengelola menjalankan Taman Bacaan maka semakin tinggi masyarakat berkunjung yang pada akhirnya meningkatkan budaya literasi masyarakat di Desa Kemiri, Pacet.

\section{KESIMPULAN}

Berdasarkan hasil pelaksanaan Pengabdian Kepada Masyarakat dalam peningkatan budaya literasi melalui penataan Taman Bacaan di Desa Kemiri dapat diambil kesimpulan:

1. Berdirinya Taman Bacaan di Desa Kemiri telah mendukung program literasi pemerintah untuk menumbuhkan kesadaran membaca masyarakat, serta mendorong perubahan sikap terhadap pentingnya membaca.

2. Pemangku jabatan dan pengambil kebijakan memiliki peran penting dalam pengembangan Taman Bacaan serta untuk menciptakan suasana dan iklim pembiasaan membaca membudaya pada masyarakat berjalan dengan baik.

3. Pengelolaan Taman Bacaan harus dilakukan dengan serius dan profesional dengan memberdayakan komponen desa yang ada seperti pemuda karang taruna dengan memberikan pelatihan-pelatihan.

4. Balai Desa dapat digunakan untuk menciptakan suasana literasi dengan kegiatan-kegiatan literasi yang mengedukasi masyarakat serta menjadi kegiatan-kegiatan yang produktif. 


\section{REFERENSI}

Ariyani, Luh Putu S., Mudana W., Atmadja, N. B., Purnawati, Desak M. O. (2017) Pemberdayaan Pemuda dalam Pengembangan Perpustakaan Desa untuk Meningkatkan Kemampuan Literasi Masyarakat. Seminar Nasional Pengabdian Kepada Masyarakat, hal. 449-455

Chiu, Hazel. (2015). Contemporary Literacy Concepts and Practices of University Students in English Language Education. International Journal of Arts and Sciences. 08(06): 213-228

Ibrahim, J.T., A. Sudiyono, dan Harpowo. (2003). Komunikasi dan Penyuluhan Pertanian. Bayumedia Publishing dan UMM Press, Malang.

Kurnia, Tommy. (2019). Skor Terbaru PISA: Indonesia Merosot di Bidang Membaca, Sains, dan Matematika. https://www.liputan6.com/global/read/ 4126480/skor-terbaru-pisa-indonesiamerosot-di-bidang-membaca-sainsdan-matematika

Menteri Dalam Negeri dan Otonomi Daerah. (2001). Keputusan Menteri dalam Negeri dan Otonomi Nomor 3 Tahun 2001 tentang Penyelenggaraan Perpustakaan Desa/Kelurahan

Rifai, Irfan and Susanto, Fajar. (2017). Narrating Literacy Practices at an Urban

Secondary School in Surabaya. Jet Adi Buana. 2(2): 189-199

Suryanto, B. (2005). Pemberdayaan Komunitas Marginal di Perkotaan dalam Dakwah Pemberdayaan Masyarakat, Paradigma Aksi Metodologi. Yogyakarta: Pustaka Pesantren.

Susanto, Fajar dan Rifai, Irfan. (2018). Teachers' Perception of Literacy Program: Its Implications to their Attitudes and Actions. Jurnal of English Teaching. 3(1): 89-100
Widjayanti, Ellita Permata dan Ayuningtyas, Fadilla. (2019). Peningkatan Budaya Literasi Anak di Taman Kanak-Kanak Nurul Fikri Bekasi Utara. Jurnal Pemberdayaan Masyarakat. 4 (1) : 291-299 